book on animal nutrition, then the leading German treatise on the subject.

Short in stature, but full of courage, outspoken and very deliberate of speech, capable of vaulting over any fence or gate that he could see over, he won the respect of the students but was too reserved to make friends among them. His wife, Minnie, daughter of Mr. R. J. Hardy, and their three children, two daughters, one of whom died in 1926, and a son, made the home an attractive place for those privileged to visit it.

In 1900 Cousins accepted the post of island chemist, Jamaica, where one of his various duties was to overhaul the manufacture of rum. He so impressed the authorities that in 1908 he was appointed director of agriculture, a post which he held until 1932. He had already in 1907 been appointed a member of the Legislative Council and retained his seat until 1923 ; his profound knowledge of the island and of its possibilities marked him out as the obvious chairman of the commission to inquire into the distressed districts.

Cousins concentrated his attention on the island problems and made little contribution to the various controversies in agricultural science that developed during the first thirty years of this century; his records are found in bis official reports and in the Jamaica Herd Book. He never lost his gift of lucid writing, however, as shown by his "History of Hope Farm".

He retired from the directorship in 1932 and in due course settled in Oxford where, through failing health, he lived in quiet retirement, taking no part in the numerous agricultural activities there going on ; the younger generation, therefore, had little opportunity of getting to know him. This was a pity, for he was a man of full knowledge and ripe experience of the type of problems now daily assuming more and more importance.

$$
\text { E. John Russelt }
$$

\section{Mr. E. G. Baker}

Edmund Ginbert Baker died at his home at Kew on December 17, at the age of eighty-five. He was the only son of John Gilbert Baker, the well-known Yorkshire botanist, who in 1866 became first assistant in and later (1890-99) keeper of the Herbarium, Royal Botanic Gardens, Kew. E. G. Baker was born at Thirsk, Yorkshire, on February 9, 1864, and received his education at Bootham School, York, and the Pharmaceutical College, London. For some time after serving an apprenticeship as a pharmacist at Chertsey he remained connected with pharmacy, and was awarded the Pereira Medal by the Pharmaceutical Society in 1886. His interest in botany was, however, already evident, and in 1887 he was appointed to a junior assistantship in the Department of Botany at the. British Museum (Natural History). $\mathrm{He}$ was elected a fellow of the Linnean Society in the same year and served on the Council during 1917-21. He retired from the staff of the British Museum in 1924, but continued to work in the Department of Botany for many years after his official retirement and was designated honorary assistant keeper.

E. G. Baker was a taxonomist of the old school. He was for a long period in charge of the Polypetalæ at the Museum and was responsible for the working out of the members of this group in many important collections received during the period he was assistant. Papers by him, often in association with colleagues, were published in the Journal of Botany, the Journal of the Linnean Society, and elsewhere. He wrote an important paper on the African species of Crotalaria (J. Linn. Soc., 42, 241; 1914). When he became independent of official duties he concentrated on African Leguminosæ and published his most important work, "The Leguminosæ of Tropical Africa", in three parts, 953 pages in all (Ghent, 1926 ; Ostend, 1929 ; Ostend, 1930). This contains generic descriptions and keys and short descriptions to the species and varieties of members of the family from tropical Africa.

E. G. Baker was closely associated with the Society of Friends and served with one of their ambulance units in the First World War. He was never married and his only sister predeceased him.

W. B. TURrILL

\section{Mrs. Evershed}

WE regret to record the death of Mary Acworth Evershed, at her home in Ewhurst on October 25. She was the fifth child of Captain Orr, R.A., and Mrs. Orr, and was born at Plymouth on January 1, 1867. Her father died when she was three years old, and her mother and family then went to live in the vicarage of South Stoke, near Bath, of which parish Mrs. Orr's father was vicar.

Even in her early days she displayed an interest in astronomy - an interest which was destined to ripen in later years into important work in this branch of science. When she was about twenty years old she went abroad, studying Italian and German and also art; afterwards she spent several years in Australia (1889-95). There she met Mr. Tebbutt, of the Observatory of Windsor, N.S.W., from whom she received a considerable amount of encouragement in her astronomical studies, and who wrote a preface to her first work, "Southern Stars".

The year following her return to England in 1895 she joined the British Astronomical Association, and went on the B.A.A. Eclipse Expeditions to Norway in 1896 and to Algiers in 1900. Arrangements were made for her to work at Dunsink Observatory in 1905, when Prof. (now Sir Edmund) Whittaker was at the University of Dublin; but the scheme did not materialize owing to her marriage in 1906 to Mr. John Evershed. When he went to Kodaikanal Observatory, India, she accompanied him, travelling by way of the United States and Japan, and visiting a number of observatories on the journey. During her stay in India she published her work, "Dante and the Early Astronomers", in 1913, and two years later her book "Stars of the Southern Skies" appeared.

Mrs. Evershed did important solar work at the Kodaikanal Observatory and contributed a memoir on prominences and also a paper in the Monthly Notices of the Royal Astronomical Society $(73,422$; 1913). She was elected a fellow of the Society in 1923, serving for a time on the Library Committee, and was also a member of the Astronomical Society of the Pacific. In 1930 she was appointed the first director of the newly formed Historical Section of the British Astronomical Association-a position which she held for fourteen years, and in which she did very valuable work. Members will remember her unfailing courtesy and prompt attention to queries relating to the historical side of astronomy. 